\title{
AGRONOMIC CHARACTERISTICS OF SORGHUM CULTIVARS FOR \\ SILAGE PRODUCTION IN THE AGRESTE OF PERNAMBUCO STATE
}

\author{
ANDRÉ LUIS ALVES NEVES ${ }^{1}$, RAFAEL DANTAS DOS SANTOS 2 , LUIZ GUSTAVO RIBEIRO \\ PEREIRA $^{3}$, JOSÉ NILDO TABOSA ${ }^{4}$, MÁRCIO ROGERS MELO DE ALMEIDA ${ }^{5}$, \\ JOSÉ AVELINO DOS SANTOS RODRIGUES ${ }^{6}$, ANSELMO LUIS ALVES NEVES ${ }^{7}$, RUI DA SILVA \\ VERNEQUE $^{1}$
}

\begin{abstract}
${ }^{1}$ Núcleo Nordeste da Embrapa Gado de Leite, Aracaju, Sergipe, Brasil, andre.neves@embrapa.br, rui.verneque@embrapa.br ${ }^{2}$ Embrapa Semiárido,Petrolina,Pernambuco,Brasil,rafael.dantas@embrapa.br ${ }^{3}$ Embrapa Gado de Leite, Juiz de Fora, Minas Gerais, Brasil, luiz.gustavo@embrapa.br ${ }_{4}^{4}$ Instituto Agronômico de Pernambuco, Recife, Pernambuco, Brasil, nildo.tabosa@ipa.br ${ }^{5}$ Engenheiro Tabuleiros Costeiros, Aracaju, SE, Brasil, rogers.melo@embrapa.br ${ }^{6}$ Embrapa Milho e Sorgo, Sete Lagoas, Minas Gerais, Brasil, avelino.rodrigues@embrapa.br 7 Engenheiro Agrônomo autônomo, anselmoluis.agro@gmail.com
\end{abstract}

$\overline{\text { Revista Brasileira de Milho e Sorgo, v.13, n.3, p. 382-390, } 2014}$

\begin{abstract}
In this study, we evaluated the productivity of green matter (PGM); productivity of dry matter (PDM); plant height (PH); percentage of lodged plants (PLP); percentage of broken plants (PBP); and proportions of panicle, stem, and leaf in the GM and DM of five sorghum genotypes (SF15, 2502, BRS655, BR506, BR601) indicated for the agreste region of Pernambuco State to assess their production of silage. The experiment was set up in a randomized block design with five treatments and five replications. SF15 was prominent for PH, with mean value of $2.24 \mathrm{~m}$. SF15, BR506 and 2502 attained the highest PDM (11.3; 11.12 and $9.54 \mathrm{t} \mathrm{ha}^{-1}$, respectively). The genotypes evaluated presented a good balance of leaf:stem:panicle ratios and were in accordance with those exhibited by sorghum genotypes selected for silage production in different Brazilian regions.
\end{abstract}

Key words: semiarid; Sorghum bicolor; ruminant; nutrition.

\section{CARACTERÍSTICAS AGRONÔMICAS DE DIFERENTES CULTIVARES DE SORGO PARA A PRODUÇÃO DE SILAGEM NO AGRESTE PERNAMBUCANO}

RESUMO - Foram avaliadas as produtividades de matéria verde (PMV), matéria seca (PMS), altura de planta (AP), porcentagem de plantas acamadas (PAC), porcentagem de plantas quebradas (PQB) e as proporções de panícula, colmo e folha na matéria verde e na matéria seca de cinco genótipos de sorgo forrageiro indicados para a região Agreste de Pernambuco (SF15, 2502, BRS655, BR506, BR601) visando à produção de silagem. Foi utilizado o delineamento experimental em blocos ao acaso, com cinco tratamentos e cinco repetições. O genótipo SF15 destacou-se em relação à altura de plantas, apresentando média de 2,24 m. Os genótipos SF15, BR506 e 2502 obtiveram as maiores produções de matéria seca $(11,3 ; 11,12$ e 9,54 t ha-1). Os genótipos avaliados apresentaram relação folha: colmo: panícula adequada para produção de silagem, indicando sua possibilidade para produção de silagem no Semiárido pernambucano.

Palavras-chave: Semiárido; Sorghum bicolor; ruminante; nutrição. 
There is a high precipitation in the agreste of Pernambuco State between April and August, followed by cycles of abundance and shortage of forage production during drought. This seasonality has diminished food availability for the herds in critical periods of the year, with negative effects on milk production systems indices.

In order to meet the demands for food in the drier periods, farmers may use conservation techniques like ensiling. This practice can solve the lack of forage over the year and, thus, ensure the maintenance of milk production all the time (Gomes et al., 2006).

Moreover, improving the production systems efficiency through the selection of sorghum genotypes for silage production can be a good alternative, since it is a forage of easy planting, drought tolerant, has high yield of green and dry matter, and characteristics that help the fermentation process, such as high content of dry matter, adequate soluble carbohydrates, and low buffering capacity (Fernandes et al., 2009; Oliveira et al., 2010). In addition, producers can reap the regrowth, which is equivalent to $60 \%$ of the first harvest (Von Pinho et al., 2007).

This study evaluated agronomic characteristics of the cultivars SF15, 2502, BRS655, BR506, and
BR601, and focused on the production of sorghum silage in the agreste of Pernambuco State.

\section{Material and Methods}

The experiment was conducted from May to August 2011 at the Experimental Station of the Agronomic Institute of Pernambuco State (IPA), in the municipality of São Bento do Una, Pernambuco State, Borborema Plateau ( $08^{\circ} 31^{\prime} 22^{\prime \prime} \mathrm{S}$ and $36^{\circ} 26^{\prime}$ 40 " W). The area has an altitude of $640 \mathrm{~m}$; annual average rainfall of $655 \mathrm{~mm}$; annual average maximum and minimum temperatures of 32.6 and $11.7^{\circ} \mathrm{C}$, respectively; a semiarid megathermal climate; and soils predominantly of sandy loam textural class, known as "psament".

Data relating to rainfall, temperature, evaporation, relative humidity, and wind velocity during the study are listed in Table 1.

The investigation used a randomized block design with five treatments and five replications. Treatments consisted of five sorghum genotypes indicated for semiarid regions (Table 2).

Plots with four rows, each $10.0 \mathrm{~m}$ in length and spaced $0.7 \mathrm{~m}$ apart, were used. Only the two central rows were considered useful areas, disregarding

TABLE 1. Meteorological data during the experimental period.

\begin{tabular}{|c|c|c|c|c|c|c|c|}
\hline \multirow{2}{*}{ Month/Year } & \multirow{2}{*}{ Days $^{1}$} & \multirow{2}{*}{$\begin{array}{c}\text { Rainfall } \\
(\mathrm{mm})^{2}\end{array}$} & \multicolumn{3}{|c|}{ Temperature $\left({ }^{\circ} \mathrm{C}\right)$} & \multirow{2}{*}{$\mathrm{RH}(\%)^{3}$} & \multirow{2}{*}{$\begin{array}{l}\text { Wind (km } \\
\left.\text { day }^{-1}\right)^{4}\end{array}$} \\
\hline & & & Max. & Min. & Mean & & \\
\hline May 2011 & 10 & 279.8 & 27.54 & 19.53 & 23.53 & 100 & 153.5 \\
\hline June 2011 & 09 & 43.1 & 27.13 & 17.35 & 22.24 & 99.69 & 163.2 \\
\hline July 2011 & 15 & 139.7 & 25.53 & 17.12 & 21.32 & 99.74 & 215.4 \\
\hline August 2011 & 12 & 19.7 & 26.88 & 16.01 & 21.44 & 99.79 & 222.3 \\
\hline
\end{tabular}

${ }^{1}$ Occurrence of rainfall in days; ${ }^{2}$ Rainfall in millimeters; ${ }^{3}$ Percentage relative humidity; ${ }^{4}$ Average wind velocity at a height of $2 \mathrm{~m}$. Source: Meteorological Station of the Experimental Station São Bento do Una, Pernambuco State of the Agronomic Institute of Pernambuco State. 
$0.5 \mathrm{~m}$ from each end. Each treatment comprised approximately 10 plants $\mathrm{m}^{-1}$, which was attained after thinning at 20 days after emergence.

Fertilization was performed according to soil analysis, which showed the following characteristics: $\mathrm{pH}$ (water): 5.1; $\mathrm{P}\left(\mathrm{mg} \mathrm{dm}^{-3}\right): 27 ; \mathrm{K}$ (cmolc dm3): 0.06; $\mathrm{Al}\left(\mathrm{cmolc} \mathrm{dm}^{-3}\right): 0.20 ; \mathrm{H}+\mathrm{Al}\left(\mathrm{cmolc} \mathrm{dm}^{-3}\right)$ : 2.22; $\mathrm{Ca}\left(\mathrm{cmolc} \mathrm{dm}^{-3}\right): 0.80 ; \mathrm{Mg}\left(\mathrm{cmolc} \mathrm{dm}^{-3}\right)$ : 0.40; O.M. $\left(\mathrm{g} \mathrm{kg}^{-1}\right)$ : 10.2 ; value of saturation $(\mathrm{S})=\mathrm{Ca}+\mathrm{Mg}$ $+\mathrm{Na}+\mathrm{K}\left(\mathrm{cmolc} \mathrm{dm}^{-3}\right)$ : 1.3; CEC (Cation-exchange Capacity $)=$ value of $\mathrm{S}+\mathrm{Al}+\mathrm{H}=1.3+2.22=3.5$ $\left(\right.$ cmolc $\left.\mathrm{dm}^{-3}\right)$; the value of CEC $(\%)=($ value of $\mathrm{S} /$ CEC) $\mathrm{x} 100=36 \%$. At sowing fertilization, we used $150 \mathrm{~kg} \mathrm{ha}^{-1}$ ammonium sulfate $+450 \mathrm{~kg} \mathrm{ha}^{-1}$ triple superphosphate $+100 \mathrm{~kg} \mathrm{ha}^{-1}$ potassium chloride. Twoside dressing fertilizations were applied, the first on the 30th day, and the second on the 60th day after plant emergence, with the dose equivalent to $150 \mathrm{~kg}$ $\mathrm{ha}^{-1}$ of ammonium sulfate.

Before fertilization, approximately $1 \mathrm{t} \mathrm{ha}^{-1}$ lime (magnesium) was applied to fix aluminum levels and raise calcium and magnesium levels.

Agronomic evaluations were performed when the plants exhibited grains in the middle of the panicle at the milky/dough stage by measuring the following: plant height $(\mathrm{PH})$; plant population (plants ha-1); productivity of green matter (PGM) $(\mathrm{t}$ $\left.\mathrm{ha}^{-1}\right)$; productivity of dry matter yield (PDM) $\left(\mathrm{t} \mathrm{ha}^{-1}\right)$; percentage of lodged plants (PLP); percentage of broken plants (PBP); and proportions of panicle, stem, and leaf in the GM and DM. Cuttings were taken at $10 \mathrm{~cm}$ above ground level. Plants in the central rows were weighed after cuttings and, based on the weight of plants in each row and their respective DM content, yields of GM and DM were calculated.

The numbers of BP (NBP) and LP (NLP) were recorded and values were transformed into percentages (NBP or NLP/total number of plants in the useful area of the plot). From each plot, a representative sample of five whole plants was weighed, packed into paper bags, and dried in a forced air oven at $65^{\circ} \mathrm{C}$ for $72 \mathrm{~h}$. Samples were withdrawn from the oven and left at a room temperature for $1 \mathrm{~h}$, after which they were weighed to determine the pre-dried matter. For DM determination, samples were ground in mills with 1-mm sieves, following the procedure of Detmann et al. (2012).

For determining the percentage of panicle, stem, and leaf in DM, five plants plot $^{-1}$ were randomly chosen. Later, the panicles, stems, and leaves of each plant were separated, weighed, and ground. The representativeness of each fraction was determined based on the resulting DM.

Variables were tested to check data normality, and later subjected to an analysis of variance, and means were compared using Tukey's test at the 5\%

TABLE 2. Agronomic description of sorghum cultivars.

\begin{tabular}{ccccc}
\hline Genotype & Type & Panicle type & Earliness $^{1}$ & Grain color \\
\hline 2502 & Dual purpose & Compact & SP & Pearly \\
SF15 & Forage & Semi-open & SE & Pearly \\
BRS 655 & Forage & Semi-open & P & Brown \\
BR 506 & Forage & Semi-open & SE & White \\
BR 601 & Forage & Semi-open & P & Red
\end{tabular}


level. Pearson correlation coefficients were also calculated. All procedures were performed using R ( R Development Core Team, 2011).

\section{Results and Discussion}

Significant differences $(p<0.05)$ were detected for PH and PLP (Table 3).

The PH of SF15 was $2.24 \mathrm{~m}$, which was superior to that of other varieties $(p<0.05)$ at a mean of 1.8 $\mathrm{m}$. In general, these results are corroborated by Tabosa et al. (2002), Neumann et al. (2002), Pinho et al. (2006) and Gomes et al. (2006), who observed significant differences in HP, with mean variation between 1.46 and $4.11 \mathrm{~m}$ for sorghum varieties (grain, forage and dual purpose) in different Brazilian regions.

It has been believed that this variable could be affected by genetic characteristics, as well as by the management techniques used for the evaluated genotypes, soil, and climatic conditions of each region.

Indeed, Silva et al. (2005a) reported that the non-inductive photoperiod can have influence on $\mathrm{PH}$ during the vegetative phase (longer than $12.9 \mathrm{~h} \mathrm{day}^{-1}$ ). According to their studies, this process can increase the formation of nodes, internodes, primordial and sprouted leaves, which can even result in high production of green and dry matter. On the other hand, plants with smaller heights present lower percentage of stems, which means better forage quality.

There was a significant difference $(\mathrm{P}<0.05)$ for PLP, with SF15 having 2.17\% and $25020.50 \%$, but similar to that of BRS 655, BR 506 and BR 601 . The mean PBP was $0.90 \%$ (Table 3)

Marchão et al. (2006) reported that PLP and PBP are associated with the crop yield and lignin content. In fact, Von Pinho et al. (2007) described them as undesirable characteristics for efficient production of silage because it is associated with mechanical harvesting and aspects of reducing losses in the field. These authors suggested that plants should be harvested at the milky/doughy stage in order to diminish these percentages, since this phenomenon increases mainly as the maturation occurs.

The values of PGM and PDM/ha, which showed a significant difference among varieties $(\mathrm{p}<$ 0.05), are listed in Table 4. Compared to 2502, BRS 655 and BR 601, BR 506 registered the highest production of PGM. Nevertheless, it was not different (p $>0.05)$ from SF15. With respect to PDM, 2502, BR 506 and SF15 excel over the others.

TABLE 3. Morphological parameters of the sorghum varieties.

\begin{tabular}{ccccc}
\hline Varieties $^{1}$ & PH $(\mathrm{m})^{2}$ & Plants ha $^{-1}$ & PLP $(\%)^{3}$ & PBP $(\%)^{4}$ \\
\hline 2502 & $1.70 \mathrm{BC}$ & 334.285 & $0.50 \mathrm{~B}$ & 0.83 \\
SF15 & $2.24 \mathrm{~A}$ & 336.571 & $2.17 \mathrm{~A}$ & 0.50 \\
BRS 655 & $1.72 \mathrm{BC}$ & 327.428 & $1.67 \mathrm{AB}$ & 1.84 \\
BR 506 & $1.76 \mathrm{~B}$ & 332.571 & $1.34 \mathrm{AB}$ & 0.34 \\
BR 601 & $1.65 \mathrm{C}$ & 323.999 & $1.51 \mathrm{AB}$ & 1.01 \\
\hline Mean & 1.8 & 330.971 & 1.44 & 0.90 \\
\hline CV (\%) & 2.89 & 2.39 & 53.0 & 94.3
\end{tabular}

${ }^{1}$ Mean values followed by the same letter, uppercase in column, are not significantly different by Tukey's test $(\mathrm{P}<0.05) .{ }^{2} \mathrm{PH}-\mathrm{Plant}$ height; ${ }^{3} \mathrm{PLP}$ - percentage of lodged plants; ${ }^{4} \mathrm{PBP}$ - percentage of broken plants. 
TABLE 4. Yields of green and dry matter of sorghum varieties.

\begin{tabular}{ccc}
\hline Varieties & PGM $\left(\mathrm{t} \mathrm{ha}^{-1}\right)^{2}$ & PGM $\left(\mathrm{t} \mathrm{ha}^{-1}\right)^{3}$ \\
\hline 2502 & $33.72 \mathrm{~B}$ & $9.54 \mathrm{~A}$ \\
SF15 & $38.42 \mathrm{AB}$ & $11.30 \mathrm{~A}$ \\
BRS 655 & $23.56 \mathrm{C}$ & $6.78 \mathrm{~B}$ \\
BR 506 & $38.74 \mathrm{~A}$ & $11.12 \mathrm{~A}$ \\
BR 601 & $18.92 \mathrm{C}$ & $5.50 \mathrm{~B}$ \\
\hline Mean & 30.67 & 8.84 \\
\hline CV $(\%)$ & 8.42 & 11.52
\end{tabular}

${ }^{\top}$ Mean values followed by the same letter, uppercase in column, are not significantly different by Tukey's test $(\mathrm{P}<0.05) .{ }^{2} \mathrm{PGM}-$ production of green matter; ${ }^{3} \mathrm{PDM}$ - production of dry matter.

The averages for PGM and PDM in this investigation (30.67 and $8.84 \mathrm{t} \mathrm{ha}^{-1}$, respectively) were similar to those found by Gomes et al. (2006), Oliveira et al. (2005) and Silva et al. (2005b). However, our results were lower than those presented by Cunha \& Lima (2010), who observed mean productivity of GM of $41.75 \mathrm{tha}^{-1}$. With regards to PDM, our values were superior to those found by Silva et al. (2007), who verified an average of $6.26 \mathrm{tha}^{-1}$.

Together with quality parameters, PGM and PDM are essential for silage production because, according to Ferrari Junior et al. (2005), these are the first factors to be considered when gathering information about a specific cultivar and on the planning and design of silos.

Table 5 presents the percentage of panicle, stem, and leaf of each sorghum variety based on GM and DM. There was influence on the percentage participation of all phenological components $(\mathrm{p}<0.05)$.

SF15 exhibited the lowest percentage of panicle both in DM and GM (11.40 and $13.40 \%$, respectively). This investigation found mean participation of panicle of 19.95 and $23.74 \%$ in GM and DM, respectively.

TABLE 5. Percentage participation of panicle, stem, and leaf in the sorghum varieties.

\begin{tabular}{ccccccc}
\hline \multirow{2}{*}{ Varieties $^{1}$} & \multicolumn{2}{c}{ Panicle } & \multicolumn{2}{c}{ Stem } & \multicolumn{2}{c}{ Leaf } \\
\cline { 2 - 7 } & $\% \mathrm{GM}^{2}$ & $\% \mathrm{DM}^{3}$ & $\% \mathrm{GM}$ & $\% \mathrm{DM}$ & $\% \mathrm{GM}$ & $\% \mathrm{DM}$ \\
\hline 2502 & $21.75 \mathrm{~A}$ & $25.50 \mathrm{~A}$ & $63.25 \mathrm{BC}$ & $58.25 \mathrm{BC}$ & $15.01 \mathrm{~A}$ & $16.25 \mathrm{AB}$ \\
SF15 & $11.40 \mathrm{~B}$ & $13.40 \mathrm{~B}$ & $71.81 \mathrm{~A}$ & $66.60 \mathrm{~A}$ & $16.81 \mathrm{~A}$ & $20.01 \mathrm{~A}$ \\
BRS 655 & $23.00 \mathrm{~A}$ & $27.80 \mathrm{~A}$ & $62.40 \mathrm{BC}$ & $56.61 \mathrm{BC}$ & $14.60 \mathrm{AB}$ & $15.60 \mathrm{AB}$ \\
BR 506 & $19.64 \mathrm{~A}$ & $24.00 \mathrm{~A}$ & $69.01 \mathrm{AB}$ & $62.64 \mathrm{AB}$ & $11.36 \mathrm{~B}$ & $13.36 \mathrm{~B}$ \\
BR 601 & $24.00 \mathrm{~A}$ & $28.00 \mathrm{~A}$ & $58.75 \mathrm{C}$ & $51.25 \mathrm{C}$ & $17.25 \mathrm{~A}$ & $20.75 \mathrm{~A}$ \\
\hline Mean & 19.95 & 23.74 & 65.04 & 59.06 & 15.00 & 17.19 \\
\hline CV (\%) & 19.42 & 19.30 & 6.63 & 6.64 & 11.74 & 15.77 \\
\hline
\end{tabular}

${ }^{\mathrm{T}}$ Mean values followed by the same letter, uppercase in column, are not significantly different by Tukey's test $(\mathrm{P}<0.05) .{ }^{2} \mathrm{GM}$ - green matter; ${ }^{3} \mathrm{DM}$ - dry matter. 
Several researches have reported that there is a great variation in this parameter. For instance, Neumann et al. (2003), evaluating the behavior of sorghum varieties, detected an average of 50.31\% of panicle in DM, which was superior to that found by this study. Oliveira et al. (2005) also mentioned a large variation of panicle percentage between dual purpose and forage sorghum, with mean values between 45.34 and $60.44 \%$ in DM, which were also higher than our results.

The percentage participation of panicle is directly associated with the production of grains and has influence on the quality of forage (Neumann et al., 2003). Thereby, the selection of cultivars with higher proportion of panicle is an important criterion to obtain varieties with better nutritional values. Furthermore, according to Ferreira (2001), the more proportion of grains in DM is high, the more forage production increases.

With regard to stem, SF15 presented the highest proportions $(\mathrm{p}<0.05)$ compared to the other varieties, although it was equal to BR 506. This investigation found mean participation of stem of 65.04 and $65.04 \%$ in GM and DM, respectively.

Neumann et al. (2002) and Dalla Chiesa et al. (2008), studying two hybrids of sorghum under four cutting ages, observed lower percentages of stem compared to our research, with mean values of $46.55 \%$ and $48.65 \%$ in DM, respectively.

Some authors believed that there is a strong correlation between plant height and stem participation both in DM and GM (Neumann et al., 2003; Silva et al., 2005a). This fact may explain why SF15 excel over the others with respect to these two characteristics.

However, high percentage of stem can also be considered as an undesirable feature for forage production, since the more stem participation is, the lower nutritional value and quality of silage will be (Gomes et al., 2006).

The percentage of leaf presented difference $(\mathrm{p}<0.05)$. BR 601 was prominent with average of 17.25 and $20.75 \%$ in GM and DM, respectively. Nonetheless, it was similar to BRS 655, SF15 and 2502.

Silva et al. (2007), working in southwest Goiás State, found percentage of leaf similar to that presented by this study (20.1\% of leaves in DM). They mentioned that water availability, as well as higher temperatures during plant growth and early senescence are factors that affect the percentage of leaves.

As observed, the genotype-environment interaction has effect on the percentage of panicle, stem and leaf, and on the dry matter content (Silva et al., 1999). For this reason, Santos et al. (2010) argued that the analysis of the proportionality relationship among panicle, stem and leaf is very important because it indicates the potential of these genotypes to provide soluble carbohydrates in adequate amounts for optimal fermentation and, consequently, the production of high-quality silages with high productivity.

With respect to the different correlations, PH was positively correlated with PDM (0.61), PLP (0.43), SGM (0.63), and SDM (0.65). On the other hand, PDM was positively correlated with SGM (0.70) and SDM (0.73) (Table 6).

It was fairly evident that both SF15 and BR 506, which showed the highest $\mathrm{PH}$, also presented the highest PDM, proportion of stem, and PLP.

Although PH has been used as an outstanding tool to make sorghum selection in the last few years, it has been suggested other criterions to undertake it (Tomich et al., 2004). In fact, Flaresso et al. (2000) 
explained that this variable should be combined not only with PDM, but also with high-quality digestible fiber because both can affect the silage quality and productivity.

Among the variables, \%PGM and \%PDM were negatively correlated with SGM, SDM (-0.91, $-0.87,-0.84$ and -0.85 , respectively), PGM and PDM $(-0.57,-0.54,-0.58$ and -0.53 , respectively), which shows effect of dilution of this component with an increasing proportion of the other plant components.

According to Flaresso et al. (2000), the determination of the panicle fraction is fundamental because it is positively correlated with the increase in the content of DM, production of grains and silage quality and, thus, it should be included as a criterion for selecting sorghum varieties for silage production.

Other correlation coefficients for the variables evaluated are in accordance with those presented for sorghum genotypes devoted to silage production in different Brazilian regions, indicating the possibility of using these materials for silage production in the northeastern semiarid region.

\section{Conclusions}

BR 506 excelled in agronomic characteristics for silage production in the Borborema Plateau, a semiarid zone of Pernambuco State.

\section{Referências}

CUNHA, E. E.; LIMA, J. M. P. Caracterização de genótipos e estimativa de parâmetros genéticos de características produtivas de sorgo forrageiro. Revista Brasileira Zootecnia, Viçosa, MG, v. 39, n. 4, p. 701-706, 2010.

DALLA CHIESA, E.; ZIEGLER ARBOITTE, M.; BRONDANI, I. L.; GLASENAPP, D.

TABLE 6. Correlation coefficients of studied variables in sorghum genotypes.

\begin{tabular}{|c|c|c|c|c|c|c|c|c|c|c|c|}
\hline Variable & PP & LP & BP & PGM & PDM & $\% \mathrm{PGM}$ & $\% \mathrm{PDM}$ & $\%$ SGM & $\% \mathrm{SDM}$ & $\%$ LGM & $\% \mathrm{LDM}$ \\
\hline $\mathrm{PH}$ & 0.34 & 0.43 & -0.24 & 0.54 & 0.61 & -0.74 & -0.74 & 0.63 & 0.65 & 0.17 & 0.22 \\
\hline PP & - & 0.04 & -0.69 & 0.40 & 0.36 & -0.21 & -0.21 & 0.21 & 0.28 & -0.04 & -0.11 \\
\hline LP & - & - & -0.09 & -0.12 & 0.00 & -0.19 & -0.18 & 0.18 & 0.17 & -0.01 & 0.04 \\
\hline BP & - & - & - & -0.24 & -0.30 & 0.17 & 0.13 & -0.22 & -0.16 & 0.14 & 0.05 \\
\hline PGM & - & - & - & - & 0.95 & -0.57 & -0.54 & 0.70 & 0.75 & -0.37 & -0.32 \\
\hline PDM & - & - & - & - & - & -0.58 & -0.53 & 0.70 & 0.73 & -0.37 & -0.30 \\
\hline$\% \mathrm{PGM}$ & - & - & - & - & - & - & 0.97 & -0.91 & -0.87 & -0.08 & -0.27 \\
\hline$\% \mathrm{PDM}$ & - & - & - & - & - & - & - & -0.84 & -0.85 & -0.17 & -0.36 \\
\hline$\% \mathrm{SGM}$ & - & - & - & - & - & - & - & - & 0.95 & -0.34 & -0.11 \\
\hline$\% \mathrm{SDM}$ & - & - & - & - & - & - & - & - & - & -0.31 & -0.18 \\
\hline$\%$ LGM & - & - & - & - & - & - & - & - & - & - & 0.88 \\
\hline
\end{tabular}

PH - Plant height; PP - Plant Populations; LP - Lodged plants (\%); BP - Broken plants (\%); PGM - production of green matter; PDM - production of dry matter; \%PGM - Proportion of panicle in the green matter; \%PDM - Proportion of panicle in the dry matter; \%SDM - Proportion of stem in the green matter; \%SDM - Proportion of stem in the dry matter; \%LGM - Proportion of leaf in the green matter; $\%$ LDM - Proportion of leaf in the dry matter. 
E.; MENEZES, L. Aspectos agronômicos de híbridos de sorgo (Sorghum bicolor (L.) Moench) no desempenho e economicidade de novilhos confinados. Acta Scientiarum. Animal Sciences, v. 30, n. 1, p. 67-73, 2008.

DETMANN, E.; SOUZA, M. A.; VALADARES FILHO, S.C.; QUEIROZ,A.C.;BERCHIELLI, T. T. ; SALIBA, E. O. S.; CABRAL, L. S.; PINA, D. S.; LADEIRA, M. M.; AZEVÊDO, J. A. G. Métodos para análise de alimentos. 1. ed. Visconde do Rio Branco: Suprema, 2012. $214 \mathrm{p}$.

FERNANDES, F. E. P.; GARCIA, R.; PIRES, A. J. V.; PEREIRA, O. G.; CARVALHO, G. G. P. de; OLIVINDO, C. de S. Ensilagem de sorgo forrageiro com adição de ureia em dois períodos de armazenamento. Revista Brasileira de Zootecnia, Viçosa, MG, v. 38, n. 11, p. 21112115, 2009.

FERRARI JUNIOR, E.; POSSENTI, R. A.; LIMA, M. L. P.; NOGUEIRA, J. R.; ANDRADE, J. B. Características, composição química e qualidade de silagens de oito cultivares de milho. Boletim de Indústria Animal, Nova Odessa, v. 62, n. 1, p. 19-27, 2005.

FERREIRA, J. J. Características qualitativas e produtivas da planta de milho e sorgo para silagem. In: CRUZ, J. C.; PEREIRA FILHO, I. A.; RODRIGUES, J. A. S.; FERREIRA, J. J. (Ed.). Produção e utilização de silagem de milho e sorgo. Sete Lagoas: Embrapa Milho e Sorgo, 2001a., cap. 15, p. 383-404.

FLARESSO, J. A.; GROSS, C. D.; ALMEIDA, E. D. Cultivares de milho (Zea mays L.) e Sorgo (Sorghum bicolor (L.) Moench.) para ensilagem no alto Vale do Itajaí, Santa Catarina. Revista Brasileira de Zootecnia, Vicosa, MG, v. 29, n. 6, p. 1608-1615, 2000.

GOMES, S. O.; PITOMBEIRA, J. B.; NEIVA, J. N. M. Comportamento agronômico e composição químico-bromatológico de cultivares de sorgo forrageiro no Estado do Ceará1. Revista Ciência Agronômica, Fortaleza, v. 37, n. 2, p. 221-227, 2006.

MARCHÃO, R. L.; BRASIL, E. M.; XIMENES, P. A. Interceptação da radiação fotossinteticamente ativa e rendimento de grãos do milho adensado.

Revista Brasileira de Milho e Sorgo, Sete Lagoas, v. 5, n. 2, p. 170-181, 2006.

NEUMANN, M.; RESTLE, J. ; ALVES FILHO, D. C.; BRONDANI, I. L.; PELLEGRINI, L. G.; FREITAS, A. K. Avaliação do valor nutritivo da planta e da silagem de diferentes híbridos de sorgo (Sorghum bicolor (L.) Moench). Revista Brasileira de Zootecnia, Viçosa, MG, v. 31, n. 1, p. 293-301, 2002.

NEUMANN, M.; RESTLE, J.; BRONDANI, I. L.; NORNBERG, J. L.; MELLO, R. O.; PELLEGRINI, L. G.; SOUZA, A. N. M. Comportamento produtivo e custo de produção de híbridos de sorgo (Sorghum bicolor (L.) Moench) para silagem. Revista Brasileira de Milho e Sorgo, Sete Lagoas, v. 2, n. 3, p. 4354, 2003.

OLIVEIRA, L. B.; PIRES, A. J. V.; VIANA, A. E. S. Produtividade, composição química e características agronômicas de diferentes forrageiras. Revista Brasileira Zootecnia, Viçosa, MG, v. 39, n. 12, p. 2604-2610, 2010.

OLIVEIRA, R. P.; FRANÇA, A. F. S.; FILHO, O. R.; OLIVEIRA, E. R.; ROSA, B.; SOARES, T. V.; Susana Queiroz Santos MELLO, S. Q. S. Características agronômicas de cultivares de sorgo (Sorghum bicolor (L.) Moench) sob três 
doses de nitrogênio. Pesquisa Agropecuária Tropical, Goiania, v. 35, n. 1, p. 45-53, 2005. PINHO, R. G. V.; VASCONCELOS, R. C.; BORGES, I. D. Influência da altura de corte das plantas nas características agronômicas e valor nutritivo das silagens de milho e de diferentes tipos de sorgo. Revista Brasileira de Milho e Sorgo, Sete Lagoas, v. 5, n. 2, p. 266-279, 2006.

R DEVELOPMENT CORE TEAM.. R: A language and environment for statistical computing. Vienna: $\mathrm{R}$ Foundation for Statistical Computing, 2011.

SANTOS, R. D.; PEREIRA, L. G. R. ; NEVES, A. L. A. ; AZEVEDO, J. A. G.; MORAES, S. A. ; COSTA, C. T. F. Características agronômicas de variedades de milho para produção de silagem. Acta Scientiarum. Animal Sciences, Maringa, v. 32, n. 4, p. 367-373, 2010.

SILVA, A. G. ; ROCHA, V. S.; CRUZ, C. D. ; SEDIYAMA, T. ; PINTO, G. H. F. Adaptabilidade e estabilidade de cultivares de sorgo forrageiro semeados em diferentes épocas do ano. Revista Brasileira de Milho e Sorgo, Sete Lagoas, v. 4, n. 1, p. 112-125, $2005 b$.

SILVA, A. G.; BARROS, A. S.; ITAMAR ROSA TEIXEIRA, I. R. Avaliação agronômica de cultivares de sorgo forrageiro no sudoeste do estado de Goiás em 2005. Revista Brasileira de Milho e Sorgo, Sete Lagoas, v. 6, n. 1, p. 116-127, 2007.
SILVA, A. G.; ROCHA, V. S.; CECON, P. R.; PORTUGAL, A. F.; PINA FILHO, O. C. Avaliação dos caracteres agronômicos de cultivares de sorgo forrageiro sob diferentes condições termofotoperiódicas. Revista Brasileira de Milho e Sorgo, Sete Lagoas, v. 4, n. 1, p. 28-44, 2005a.

SILVA, J.M.;FEIJÓ, G.L.;PORTO, J.C.A.;THIAGO, L. R. L. S.; KICHEL, A. N. Desempenho animal e avaliação do potencial produtivo de forragens para ensilagem, por intermédio de diferentes fontes de suplementação nitrogenada. Revista Brasileira de Zootecnia, Vicosa, MG, v. 28, n. 3, p. 642 - 653, 1999.

TABOSA, J. N.; REIS, O. V.; BRITO, A. R. M. B. Comportamento de cultivares de sorgo forrageiro em diferentes ambientes agroecológicos dos estados de Pernambuco e Alagoas. Revista Brasileira de Milho e Sorgo, Sete Lagoas, v. 1, n. 2, p. 47-58, 2002.

TOMICH, T. R.; RODRIGUES, J. A. S.; TOMICH, R. G. P.; GONÇALVES, L. C.; BORGES, I. Potencial forrageiro de híbridos de sorgo com capim-sudão. Arquivo Brasileiro de Medicina Veterinária e Zootecnia, Belo Horizonte, v. 56, n. 2, p. 258-263, 2004.

VON PINHO, R. G.; VASCONCELOS, R. C.; BORGES, I. D. Produtividade e qualidade da silagem de milho e sorgo em função da época de semeadura. Bragantia, Campinas, v. 66, n. 2, p. 235-245, 2007. 